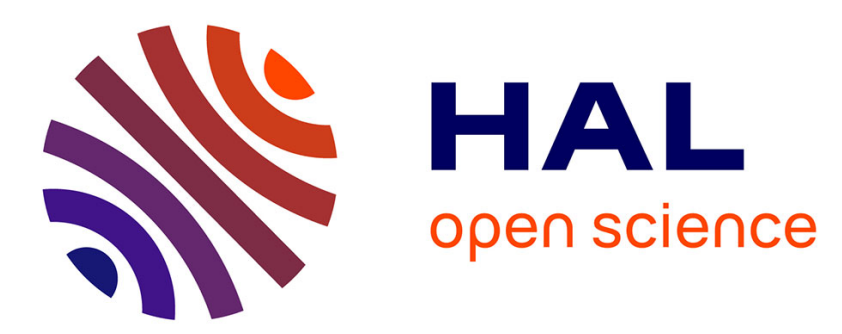

\title{
Weed control modifies Tuber melanosporum mycelial expansion in young oak plantations
}

Antoni Olivera, José Antonio Bonet, Lorena Palacio, Bing Liu, Carlos Colinas

\section{To cite this version:}

Antoni Olivera, José Antonio Bonet, Lorena Palacio, Bing Liu, Carlos Colinas. Weed control modifies Tuber melanosporum mycelial expansion in young oak plantations. Annals of Forest Science, 2014, 71 (4), pp.495-504. 10.1007/s13595-014-0360-x . hal-01102226

\section{HAL Id: hal-01102226 \\ https://hal.science/hal-01102226}

Submitted on 12 Jan 2015

HAL is a multi-disciplinary open access archive for the deposit and dissemination of scientific research documents, whether they are published or not. The documents may come from teaching and research institutions in France or abroad, or from public or private research centers.
L'archive ouverte pluridisciplinaire HAL, est destinée au dépôt et à la diffusion de documents scientifiques de niveau recherche, publiés ou non, émanant des établissements d'enseignement et de recherche français ou étrangers, des laboratoires publics ou privés. 


\title{
Weed control modifies Tuber melanosporum mycelial expansion in young oak plantations
}

\author{
Antoni Olivera • José Antonio Bonet • Lorena Palacio • \\ Bing Liu $\cdot$ Carlos Colinas
}

Received: 14 July 2013 / Accepted: 13 January 2014 /Published online: 27 February 2014

(C) INRA and Springer-Verlag France 2014

\begin{abstract}
- Context Black truffle (Tuber melanosporum) cultivation is a promising agro-forestry alternative for Mediterranean rural areas, but adequate weed control at seedling establishment still remains a challenge in black truffle plantations.

- Aims The aim of this study is to evaluate the effects of several weed control strategies on early development of Quercus ilex seedlings and the symbiotic T. melanosporum.

- Materials and methods In a young black truffle-inoculated holm oak plantation, we assessed for 3 years the effects of two types of mechanical weed control and five mulches in a young $Q$. ilex plantation inoculated with T. melanosporum. Herbaceous cover, seedling growth and abundance of T. melanosporum mycelium, based on PCR analysis of soil DNA extracts using T. melanosporum-specific primers, were estimated to determine the effectiveness of these treatments in controlling weeds and supporting the growth of both the host tree and the target fungus.
\end{abstract}

Handling Editor: Ana Rincon

Contribution of the co-authors José Antonio Bonet: writing and supervising the work

Lorena Palacio: running laboratory and field works

Bing Liu: running laboratory and field works

Carlos Colinas: coordinating the research project and writing and supervising the manuscript

A. Olivera $(\varangle) \cdot$ J. A. Bonet $\cdot$ B. Liu $\cdot$ C. Colinas

Department of Crop and Forest Sciences, School of Agrifood and

Forestry Science and Engineering (ETSEA), University of

Lleida-Agrotecnio Center (UdL-Agrotecnio), Avenida Alcalde

Rovira Roure 191, 25198 Lleida, Spain

e-mail: antoni.olivera@pvcf.udl.cat

J. A. Bonet $\cdot$ L. Palacio $\cdot$ B. Liu $\cdot$ C. Colinas

Forest Sciences Centre of Catalonia (CTFC), Crta. Sant Llorenç de

Morunys km 2, 25280 Solsona, Spain
- Results The amount of T. melanosporum mycelium in the soil $30 \mathrm{~cm}$ around the seedlings was larger under double-layer white mulch than in the rest of treatments tested. Under the white colour mulches, which had the largest light reflection, we registered the cooler soil temperature, and the best weed control was observed on the single- and double-layer black truffles and double-layer white mulch.

- Conclusion The effects of double-layer white mulch on herbaceous cover, soil temperature, reflected light, and the expansion of T. melanosporum bring us closer to being able to substitute traditional tilling of truffle orchards for the less expensive mulching treatments.

Keywords Tubermelanosporum · Quercus ilex · Mulch · Soil mycelium $\cdot$ Weed control

\section{Introduction}

Black truffles are the edible fruiting bodies of Tuber melanosporum Vittad., an ectomycorrhizal fungus that evolved with its symbiotic host trees in the Mediterranean region, characterized by seasonal strong water deficits. Because the black truffle has an important commercial value due to its gastronomic fame, its cultivation has strong positive financial rewards for landowners helping to promote new rural economies supported by seedling nurseries, canning industries or tourism (Samils et al. 2008; Lefevre and Hall 2001). This fungus exerts a phytotoxic effect on the root system of many herbaceous species acting as a natural herbicide. As a result, colonized trees are surrounded by an area lacking competing vegetation, known as 'burn' or 'brûle', a few years before the appearance of the first truffles. But before the burn appears, young seedlings may suffer serious competition from weeds that can lead to plantation failure by constraining the development of both host and fungus (Bonet et al. 2006; Olivera et al. 2011). 
Conventional methods of weed control in truffle orchards rely primarily on tillage and hand hoe for a few years after planting, which are labour intensive or may adversely affect soil structure and cause excessive breakdown of aggregates (Reicosky et al. 2003). In these orchards, the use of mulches could be an alternative to weed control. However, it is a novel approach whose results must be thoroughly tested, mainly due to the wide range of materials available as well as the lack of published results of their effects on both tree and fungus development. The synthetic mulches of opaque black polypropylene fabric are widely used to reduce weed germination and growth in agricultural crops (Verdú and Mas 2007). However, black mulches seem to increase the presence of ectomycorrhizal competitors in T. melanosporum plantations (Bourrieres and Ricard 2008). The increase of both soil moisture and soil temperature induced by black mulches (Ramakrishna et al. 2006) favours competing ectomycorrhizal fungi (Zambonelli et al. 2005). White fabric mulches that reflect light and reduce soil warming (Heißner et al. 2005) may help reduce water evaporation from soil during the driest periods, but being translucent, they allow the germination and growth of weeds. Reflective materials increase the light available to the host trees in spring and fall, when neither water nor temperature is limiting for photosynthesis (Pinty et al. 2011). Variation in light availability modifies the species of ectomycorrhizal fungi associated with the host plant as was demonstrated in Abies balsamea L. seedlings (Kummel and Lostroh 2011).

An added difficulty to this type of field experimentation is the need to establish reliable response variables since we cannot visually observe the belowground mycelium proliferation or the potential competition from other fungi. Because there will be no black truffle production in the first few years of a plantation, other indicators of the success of the treatments are needed. The presence of T. melanosporum mycelium in the soil could be a good indicator for future black truffle production as it has been observed in previous research with T. melanosporum (Parladé et al. 2013; Zampieri et al. 2012), Hebeloma cylindrosporum (Guidot et al. 2002), and Lactarius deliciousus (Parladé et al. 2007).

Even though the presence of mycelium of T. melanosporum cannot guarantee the emergence of black truffles, its presence is a necessary prerequisite for fruit body formation (Kües and Martin 2011). Suz et al. (2006) established a method of mycelium quantification from soil with conventional PCR and a calibration curve based on known quantities of black truffle mycelium. With this method, we can detect up to $11.4 \mu \mathrm{g}$ of T. melanosporum hyphae per gram of soil, which allows us to have enough resolution to compare the effects of different weed control strategies on T. melanosporum mycelium in the soil.

The objectives of this study were to evaluate the impacts of several strategies to control the herbaceous cover during the establishment of black truffle orchards. We hypothesized that effective weed control can enhance T. melanosporum abundance and distribution in the soil by promoting the development of the host tree; however, the strategy used to manage the herbaceous cover might act on soil water, soil temperature and light availability to the host plants, and possibly favour only one of the symbiotic partners, unbalancing the belowground system. So, black mulches may be more effective in reducing weeds but may make the temperature too high for T. melanosporum. On the other hand, stone mulching may slowly release calcium carbonate and thus favour the fungus but allow the growth of competing vegetation that would increase the tree's water stress.

To evaluate the success of weed control, we measured seedling growth in height and stem diameter for 3 growing years in the field and T. melanosporum mycelium abundance and extension after the third growing season. The effects of these weed control methods on soil temperature, soil moisture and photosynthetic photon flux density (PPFD) were monitored to explain possible mechanisms of action of weed control treatments.

\section{Material and methods}

\subsection{Establishment of the experiment}

The study was conducted in a plantation located in the eastern Pre-Pyrenees of Spain $\left(45^{\circ} 15^{\prime} 0.19^{\prime \prime} \mathrm{N}, 0^{\circ} 46^{\prime} 26.5^{\prime \prime} \mathrm{E}\right)$ at $834 \mathrm{~m}$ a.s.l. with $5 \%$ slope where the parent material is calcareous sedimentary rock. The climate is Mediterranean continental with seasonal mean temperatures over the last 40 years ranging from $4{ }^{\circ} \mathrm{C}$ in winter to $22{ }^{\circ} \mathrm{C}$ in summer. The mean annual precipitation and temperature are $725 \mathrm{~mm}$ and $12{ }^{\circ} \mathrm{C}$. During the 3 years of the study, the annual precipitations were 589,816 and $913 \mathrm{~mm}$, and the reference evapotranspirations (Allen et al. 1998) were 856, 899 and $959 \mathrm{~mm}$ respectively. The soil physical and chemical properties are shown in Table 1. The truffle orchard was established in

Table 1 Soil nutrients and physical and chemical properties for the study site

\begin{tabular}{ll}
\hline Nitrogen (Kjeldahl) $(\%)$ & 0.17 \\
Phosphorus (Olsen) $\left(\mu \mathrm{g} \mathrm{g}^{-1}\right)$ & 11 \\
Potassium (\% of potassium oxide) & 112 \\
Organic material $(\%)$ & 3.53 \\
Calcium carbonate $(\%)$ & 41 \\
Sand $(0.05<d<2.00 \mathrm{~mm}) \%$ & 51.9 \\
Clay $(d<0.002 \mathrm{~mm}) \%$ & 17.3 \\
Soil $\mathrm{pH}\left(\mathrm{H}_{2} \mathrm{O}\right)$ & 8.3 \\
Soil texture $(\mathrm{USDA})$ & Sandy loam \\
\hline
\end{tabular}


May 2007 with holm oak seedlings (Quercus ilex L.) inoculated with T. melanosporum from a commercial nursery. Prior to outplanting, the T. melanosporum colonization percent of seedlings in the selected lot ranged from 38 to $67 \%$, and they were free of mycorrhizae different from T. melanosporum. The site was originally forestland that had been cleared and cropped with a combination of fescue and barley for 15 years prior to the establishment of the black truffle plantation. Plantation establishment required ripping the soil to a depth of $60 \mathrm{~cm}$ to break up hardpans and promote deep soil aeration, and then superficial tilling with several passes to provide a planting zone free of herbaceous vegetation.

We chose this site because the surrounding forest, mainly composed of holm and downy (Quercus pubescens Willd.) oaks, has productive wild black truffle beds. Due to the soil and climate characteristics, the site has been considered as representative of Mediterranean environments where black truffles grow (Colinas et al. 2007). The truffle orchard was never irrigated for the 3 years of our study.

\subsection{Experimental design}

Seedlings were planted in rows of $6 \times 3 \mathrm{~m}$. The experiment followed a random design with weed control as a main factor. In total, eight treatments were repeated eight times. Each treatment was applied in a $2 \times 2-\mathrm{m}$ square (plot) surrounding each inoculated seedling. An experimental unit consisted of two neighbouring plots with the same treatment.

\subsection{Weed control strategies}

We tested seven different strategies for reducing herbaceous cover in this plantation. Five ground cover mulches were used. Black and white woven polypropylene fabrics of $110 \mathrm{~g} \mathrm{~m}^{-2}$, with both single and double layers of each, resulting in four different fabric mulching treatments: black single, black double, white single and white double. Another mulching treatment was white calcareous 3-6-cm-diameter stones, with a depth of $8-10 \mathrm{~cm}$ (stone mulch). We used two mechanical weed control treatments: soil tilling with cultivator tines set at 6-8 $\mathrm{cm}$ deep and manual weed control with a hand hoe, both performed twice a year, in May and September. For control, we used untreated plots.

\subsection{Measured variables}

Total natural herbaceous cover was estimated visually by the same person in every plot and expressed as percent cover. In the case where the soil surface was covered by polypropylene fabric, we removed it and then replaced it after completing the observation. In the plots with stone mulch, we included all the herbaceous growth among the stones. The herbaceous cover was estimated in October of every year for 3 years.
We recorded seedling height and stem diameter $2 \mathrm{~cm}$ above ground level in December of every year. Reference marks were painted on each seedling to ensure that repeated diameter measurements were taken at the same height. Survival was also assessed at this time.

Thermometers (TMC20-HD, Onset Computer Corporation, Bourne, MA, USA) and soil water content probes (ECH2O soil moisture, Decagon Devices, Inc., Pullman, WA, USA) were installed in three replications of all the treatments. We recorded data in loggers (Onset Computer Corporation, Bourne, MA, USA) every hour. Thermometers were calibrated in our laboratory, and soil moisture content probes were calibrated according to the manufacturer's directions using a gravimetric method based on soil cores taken from every plot where probes were installed. We repeated the calibration three times with three extremely different soil moisture conditions. Thermometers were positioned in the soil $15 \mathrm{~cm}$ deep, and soil moisture probes, which were $20 \mathrm{~cm}$ long, measured moisture from 10 to $30 \mathrm{~cm}$ deep. We used the Saxton-Rawls method to estimate the volumetric soil water content at field capacity and permanent wilting point (Saxton and Rawls 2006).

Both direct and reflected PPFD were measured with a ceptometer (Accupar LP-80, Decagon Devices, Inc., Pullman, WA, USA) oriented to the zenith and placed $20 \mathrm{~cm}$ out from the stem of the seedling and $30 \mathrm{~cm}$ above ground. The reflective to incident PPFD ratio is reported as percent of reflected PPFD for each treatment.

\subsection{Soil sampling and molecular analyses}

In December 2009, one seedling from each experimental unit was chosen randomly to test for T. melanosporum mycelium development belowground. A set of subsamples were taken at $15,30,45$ and $60 \mathrm{~cm}$ from the seedlings. The samples were taken under the mulches that reached $1 \mathrm{~m}$ from the seedling. At each sampling distance, we took a different number of samples in order to have a number of samples proportional to the length of the circumference at all four distances and, this way, have the same likelihood of detecting fungal presence at each distance. We took 4 samples at $15 \mathrm{~cm}, 8$ subsamples at $30 \mathrm{~cm}, 12$ subsamples at $45 \mathrm{~cm}$ and 16 subsamples at $60 \mathrm{~cm}$.

All subsamples from the same distance were pooled into one sample. The samples at 45 and $60 \mathrm{~cm}$ did not yield T. melanosporum in our preliminary testing, and thus, we only refer in this paper to the soil samples at 15 and $30 \mathrm{~cm}$. We used the $60-\mathrm{cm}$ soil DNA extractions as negative controls in later PCR runs. All samples were sieved to $2 \mathrm{~mm}$, homogenized and stored at $4{ }^{\circ} \mathrm{C}$ in a field cooler and then stored at $-20{ }^{\circ} \mathrm{C}$ in the laboratory. A total of 128 soil samples were collected, 2 from each experimental unit representing 15 and $30-\mathrm{cm}$ distances from the trunk. DNA extractions from all samples were carried out with the Power Soil DNA Isolation Kit (MO BIO 
Laboratories, Inc., Carlsbad, CA, USA). We used $0.50 \mathrm{~g}$ of soil for each extraction and then diluted the product to $1 / 1,000$. From this solution, we used $5 \mu \mathrm{l}$ as template in the PCR with puReTaq Ready-To-Go PCR Beads (GE Healthcare, Little Chalfont, Buckinghamshire, UK) in a final volume of $25 \mu$ l. The primers used, which are specific for T. melanosporum, were ITSML/ITS4LNG (Paolocci et al. 2000): ITSML (5'-TGGCCATGTGTCAGATTTAGTA-3') and ITS4LNG (5'-TGATATGCTTAAGTTCAGCGGG-3'). The PCR was carried out in a thermocycler (Biometra, Göettingen, Germany) using the program proposed by Rubini et al. (1998). Total DNA in extractions was measured by spectrophotometry (NanoDrop 1000, Thermo Fisher Scientific Inc., Waltham, MA, USA). Electrophoresis ran for $40 \mathrm{~min}$ in $1 \%$ agarose gel (Agarose MS-8, Laboratorios Conda, Torrejón de Ardoz, Spain), with settings at $70 \mathrm{~V}$, $300 \mathrm{~mA}$.

We estimated the amount of T. melanosporum mycelium in our soil samples by comparing the size and density of the electrophoresis bands of the PCR products of their extractions with those of a standard with a known amount of mycelium (Suz et al. 2006). We constructed our standard by mixing fresh gleba of T. melanosporum with fresh soil in a porcelain mortar in the following concentrations: $1.46,2.90,5.72,11.4,22.9$, $45.8,91.6,183,366,732,1,465$ and $2,930 \mu \mathrm{g}$ of T. melanosporum per gram of soil. Every gel contained eight soil samples, each from one replication of the eight treatments, a positive control from ascomata of T. melanosporum gleba, a negative control from one soil sample taken $60 \mathrm{~cm}$ from the trunk without $T$. melanosporum presence, a blank with water, and one standard set with nine concentrations. The gels were scanned and analyzed with Gel Doc 2000-QuantityOne software (Bio-Rad Laboratories, Hercules, CA, USA) to measure the size and density of the bands. Each gel was scanned three times, and we used the average of the three readings to reduce the variability.

\subsection{Statistical analyses}

Two neighbouring seedlings with the same treatment were considered one experimental unit. We used the average of all measured variables of these two seedlings to compare seedling height and diameter, herbaceous cover and percent of reflected PPFD. Mycelium abundance was estimated in only one of the two neighbouring trees, which was chosen randomly. In the case of soil sampling, distance from the tree trunk was considered within-group factor. Tests for normality (ShapiroWilk) and constant variance (Levene) were performed, and data transformations were made when necessary to ensure the validity of these assumptions. When variables were transformed, their means were back transformed to the original scale and reported as medians (Ramsey and Schafer 2002). Because our soil sampling design with weed control treatment and distances from the stem corresponds to a randomized design with repeated measures, we analyzed the observations by MIXED procedure (SAS Institute Inc. 1999), which treats both factors, treatments and distances, as a factorial experiment. Moreover, the procedure contains the option to calculate approximate $F$ tests using Satterthwatie's method to estimate degrees of freedom associated with different error structures inherent to complex designs and has the capability to select the most appropriate covariance structure that minimizes Akaike's information criterion and Schartz's Bayesian criterion for repeated measures (Littell et al. 2006). Fischer's protected least significant difference procedure was used to separate means at $p<0.05$.

\section{Results}

\subsection{Weed control}

The treatment, the year and their interaction significantly influenced herbaceous cover over the course of the 3 years of this study, all three with $p \leq 0.0001$. In all treatments, herbaceous cover increased over the years except in the double fabric mulched plots (Fig. 1). Untreated plots showed significant differences between first and second sampling but not between second and third sampling.

Over the 3 years, the lowest percent herbaceous cover was observed in black single, black double and white double, where medians did not exceed $10 \%$, while the highest percents were observed in the untreated and white single plots, which had over $90 \%$ herbaceous cover. Stone mulch and mechanically weeded plots maintained herbaceous cover at nearly half that observed in the untreated plots (Fig. 1). Black and stone mulch treatments showed lower herbaceous cover compared with the rest of treatments, but stone mulch was

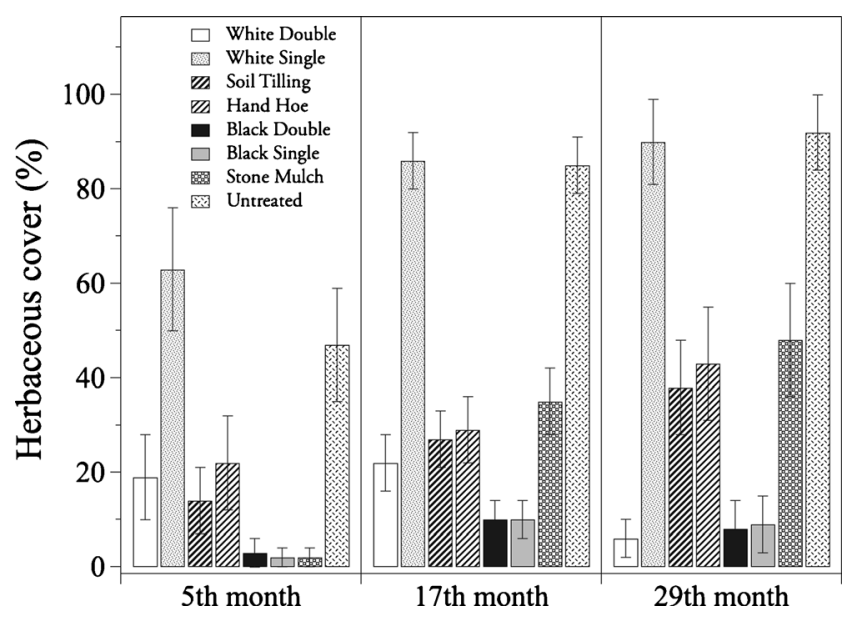

Fig. 1 Medians of percentage of herbaceous cover in the eight weed control treatments, 5, 17 and 29 months after truffle-oak seedling plantation. Vertical bars represent $95 \%$ confidence intervals 
only effective during the first year. Weeds in the untreated plots started to grow in autumn; they bloom in spring and become senescent the next autumn. The dominant annual species were Brachypodium phoenicoides L., Lolium rigidum Gaud., Anagallis arvensis L., Diplotaxis erucoides L., Chenopodium album L., Setaria verticillata L., Sonchus tenerrimus L., and Calendula arvensis L., and the dominant perennials were Convolvulus arvensis L., Cynodon dactylon L., Chondrilla juncea L., and Muscari neglectum Guss.

\subsection{Survival and tree growth}

Along the study, the seedling survival rate was $99 \%$. In the second year of sampling, we recorded seven seedlings with dry leaves, although we observed new shoots at the base of the stem. These seedlings were not included in the comparative analyses.

The differences in increase of stem diameter and height of seedlings were significant across the years $(p \leq 0.0001)$. Overall, the mean increase of stem diameter was 1.91 $( \pm 0.082) \mathrm{mm}$ for the second growing year and $3.59( \pm 0.175)$ $\mathrm{mm}$ for the third growing year. The mean increase of height was $23.2( \pm 1.00)$ and $33.9( \pm 1.10) \mathrm{cm}$ for the second and third years respectively. Differences in the increase of stem diameter and height of seedlings in response to weed control strategies were also significant with a $p \leq 0.0031$ for the mean increase of stem diameter and $p \leq 0.0044$ for the mean increase of height. Interaction between growing year and weed control was not significant.

Weed control did not affect the initial observations, 7 months after planting, on both seedling height $(p \leq 0.2221)$ and stem diameter $(p \leq 0.2668)$. At this stage, seedling height and steam diameter were $21.8( \pm 4.90) \mathrm{cm}$ and $4.6( \pm 0.87) \mathrm{mm}$ respectively.

The most important effect of herbaceous control strategies on the mean increase of stem diameter occurred with the white double, white single and black single treatments with respect to seedlings in the untreated plots (Fig. 2a). In these plots, the mean increase of stem diameter of the seedlings was larger both years compared with those in the untreated plots. For the mean increase of height, the most effective treatment was white double (Fig. 2b). Interestingly, seedling height with the stone mulch treatment improved only after the second year.

\subsection{Colonization of soil by T. melanosporum}

The quantification method that we use in this study allows us to work between 2.48 and $2,368 \mu \mathrm{g}$ of soil mycelium of T. melanosporum per gram of soil. The maximum amount of T. melanosporum (microgram mycelium per gram of soil), found in a single soil sample, was 954 times the minimum. DNA of T. melanosporum was detected in $100 \%$ of the samples at 15 and $30 \mathrm{~cm}$ of distance from seedling stem, with

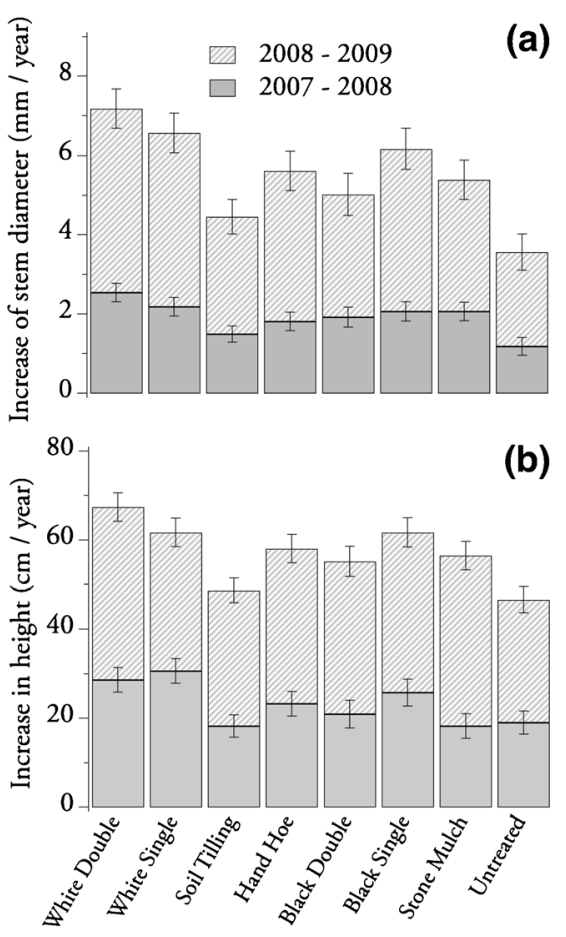

Fig. 2 Mean increase of stem diameter (a) and height (b) of T. melanosporum-inoculated oaks with different weed control strategies from December 2007 to December 2008 and from December 2008 to December 2009. Vertical bars represent $\pm 1 \mathrm{SE}$

none observed at 45 or $60 \mathrm{~cm}$ after nearly 3 years since the establishment of the black truffle orchard. We cannot discard the possibility that we did not detect the presence of T. melanosporum mycelium at greater distances from the trunk if it was under our detection capacity. However, the 128 soil samples with the presence of $T$. melanosporum were sufficient to compare the expansion of the fungus in relation to the weed control treatments.

Quantities of T. melanosporum mycelium in the soil differed significantly in both distance and weed control treatments with $p \leq 0.0001$ and $p \leq 0.0113$ respectively. The medians of T. melanosporum mycelium at 15 and $30 \mathrm{~cm}$ were 268 and $72.9 \mu \mathrm{g}$ per gram of soil respectively.

At $15 \mathrm{~cm}$, the amount of T. melanosporum mycelium of most mulching treatments was not significantly different from the untreated plots. The exception was white single mulch, which halved the amount of mycelium in the untreated plots (Fig. 3). However, at $30 \mathrm{~cm}$, soil from seedlings treated with the white double mulch had remarkably greater quantities of T. melanosporum than the rest of mulch treatments including the untreated plots.

\subsection{Soil moisture and temperature and reflected light}

We found a significant interaction $(p \leq 0.0001)$ between weed control treatments and the amount of time that the plants were below a given soil water content. Plants in stone mulch and soil 


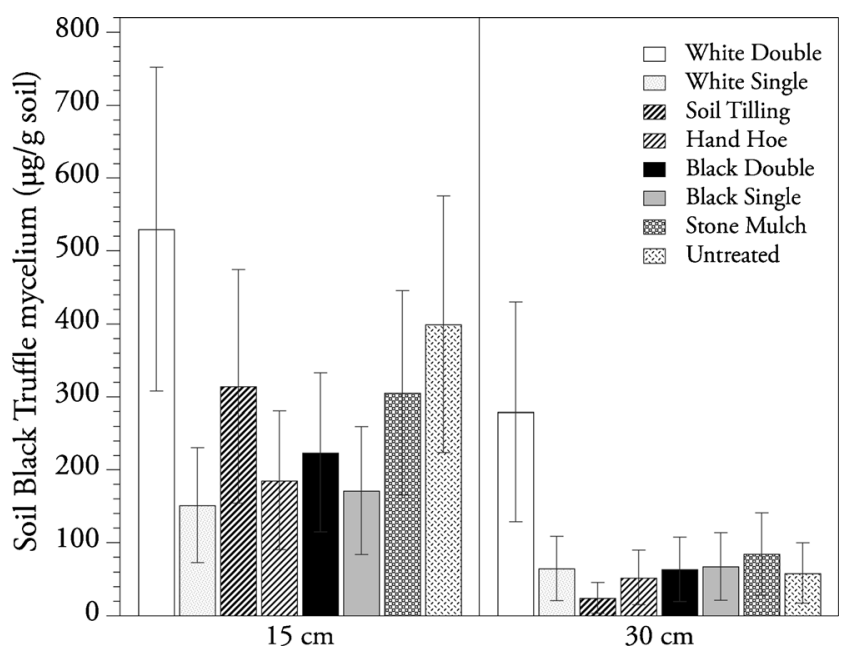

Fig. 3 Medians of T. melanosporum mycelium quantities at 15 and $30 \mathrm{~cm}$ from seedlings with different weed control strategies. Vertical bars represent $95 \%$ confidence intervals

tilling plots spent more days at low water contents than plants in untreated plots. This was particularly relevant when we measured the number of days under wilting point $(12 \%$ of soil water volume) (Fig. 4a). Plants in white double plots were fewer days under the wilting point than those in the plots of the rest of the treatments; however, we only found significant differences between white double, and stone mulch and soil tilling treatments, and occasionally white single treatment (Fig. 4a).

We also found a significant interaction between the amount of time that the plants were above a certain soil temperature and weed control treatments $(p \leq 0.0001)$. We observed significant differences among weed control treatments for each degree in temperature except for 31 and $32{ }^{\circ} \mathrm{C}$, which were very seldom reached at $15 \mathrm{~cm}$ of depth under the mulches. Important differences were found for soil temperature beneath white double, white single and stone mulch in relation to untreated plots. In these treatments, there were fewer days of extreme temperature (Fig. 4b). We did not detect a warmer soil environment under black mulches compared with the untreated plots.

The measurement of PPFD was done at the end of the study when the herbaceous presence was more developed than in the early months of the study. The plots with greater reflected light were those with white double layer and white single layer. The plots with black single, black double and hand hoe treatments and the untreated plots had the lowest percentage of reflected PPFD, with no differences among them. White double plots reflected a sixfold greater PPFD than that in untreated plots (Fig. 5).

\section{Discussion}

Weed management is an essential treatment to guarantee both survival and growth of seedlings in afforested sites (Navarro

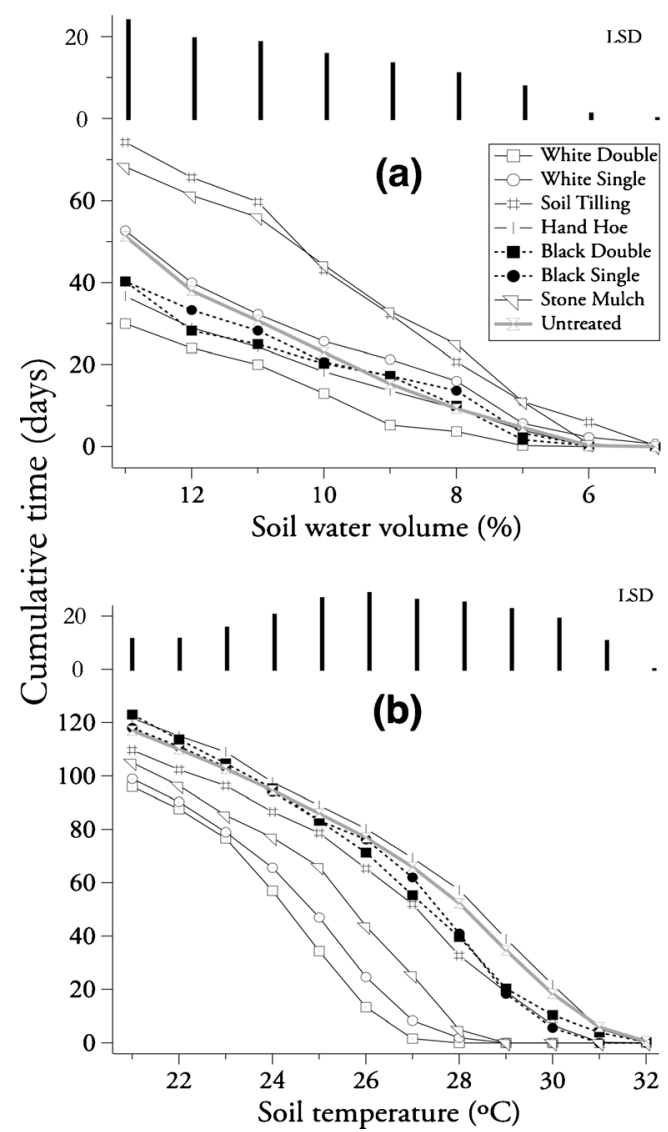

Fig. 4 Means of amount of time below a given soil water content under the wilting point (a) and the highest daily means of soil temperature (b) during 2009 observed in plots with different weed control treatments. Vertical bars above each percent of soil water volume or temperature are the least significant differences among treatments at that percent of soil water volume or temperature

Cerrillo et al. 2005) as well as to improve ectomycorrhizal fungal development (Olivera et al. 2011). This is especially important in former arable lands where the proliferation of ground vegetation after soil preparation is usually rapid as we observed in this study, where the untreated plots reached $80 \%$

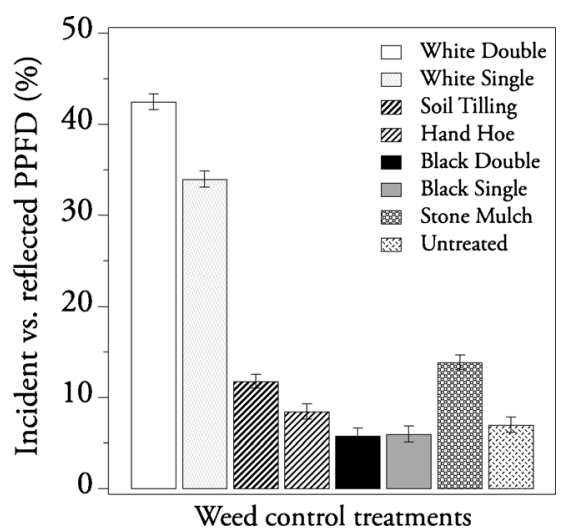

Fig. 5 Means of the percentage of reflected to incident photosynthetic photon flux density (PPFD) observed in plots with different weed control treatments. Vertical bars represent $\pm 1 \mathrm{SE}$ 
herbaceous cover 1 year after seedling plantation. The lack of significant interaction between growing year and weed control on the seedling growth points out that the effects of herbaceous cover were clear from the first year and were linear along the next 2 years. In these conditions, competition for resources between seedlings and weeds must be intense, with direct consequences for the growth and survival of seedlings (Hytonen and Jylha 2005) justifying the use of tillage and hand hoe, herbicides or mulches during the first years of establishment. Mechanical weed control has been used as the major agricultural technique for several decades by truffle growers who prefer this technique over herbicides to produce and market truffles with an organic label. We observed that mechanical weed control compared poorly with black and double white fabric covers in controlling herbaceous cover. Because mechanical activities are labour intensive and have disadvantages associated with degradation of soil structure, a reduction in frequency or intensity of tilling is recommended to limit their negative effects (Lipecki and Berbec 1997; Reicosky et al. 2003). But if the reduction in the frequency of tilling results in greater weed presence, the application of mulches could be the alternative of choice as long as tilling does not provide additional benefits for the fungus than those strictly arising from removal of weed competition.

In the present study, the percent of herbaceous cover was clearly influenced by the treatments, with significantly lower percentages in plots with black single and double and white double ( $<10 \%$ of herbaceous cover) and significantly higher for plots with white single and untreated plot $(>90 \%$ of herbaceous cover). The thicker and darker materials that suppress or block light provided better prevention of weed growth. Black mulch absorbs most of the incoming solar radiation and re-emits energy in the form of thermal radiation, while translucent polyethylene materials will transmit to the soil most of the incoming radiation, depending on the degree of opacity of the material (Rajapakse and Shahak 2007). In our plots with white double, we observed as high as $22 \%$ herbaceous cover after 17 months, but this percentage was reduced over the following 12 months of the study. By using two white sheets, we were able to increase opacity over what was provided with a single layer. Furthermore, we observed that by the second year, a fine layer of silt had accumulated in the space between both layers of the fabric, providing additional opacity. We hypothesize that this additional opacity contributed to the decrease in herbaceous cover observed after 29 months and that a combination of a white sheet above with a black one underneath might have yielded an even better result, although further studies are needed to test this hypothesis. The results for mechanical control show that with two tillage operations per year, the mean herbaceous cover was $38 \%$, while in a previous study of tillage applied once every year in a truffle orchard, Olivera et al. (2011) reported a mean of $58 \%$ of herbaceous cover after 4 years. These data support the use of mulches as a promising alternative to traditional tillage in black truffle plantations.

Despite the very dry summers, characteristic of Mediterranean climate, where mortality of seedlings is associated with dry periods (Davis et al. 1999), in the present study, only one seedling died. The low mortality observed here may be attributed to the positive effect of the symbiosis between $Q$. ilex and T. melanosporum, which has been shown to increase seedling survival (Domínguez Núñez et al. 2006; Martínez de Aragón et al. 2012). Additionally, our results suggest that the environmental conditions in this site were not as severe as in other studies where mortality was problematic with the same symbionts (Bonet et al. 2006; Olivera et al. 2011).

With the relatively moderate environmental conditions of our sites and a mean annual precipitation of $725 \mathrm{~mm}$, we observed differences in seedling stem diameter and height associated with different weed control strategies. In the untreated plots, the mean annual increase in diameter was 1.2 and $2.4 \mathrm{~mm}$ for 2007-2008 and 2008-2009 growing years respectively, the lowest growth measurements observed in any of the treatments, and not significantly different from those observed in the tilled plots. Similar results were obtained by Navarro Cerrillo et al. (2005) who found no differences in growth for $Q$. ilex seedlings treated with tillage and herbicide treatments in comparison with controls. On sites afforested with Q. ilex, Rey Benayas et al. (2005) observed no increase in mean diameter for seedlings in the untreated plots, whereas mowing and shading treatments resulted in seedling diameter increases of $3.9 \mathrm{~mm}$ after nearly 3 years. In three truffle plantations, Olivera et al. (2011) showed that annual tillage improved $Q$. ilex growth, although the best increase was observed with herbicide treatments. Since weeds may compete with holm oak seedlings for a limited supply of water, herbaceous competition can be extremely important in arid environments, with water availability as the critical explanatory factor to interpret these heterogeneous results.

However, with black truffle cultivation, the purpose is not to obtain trees with a large bole but to promote a welldeveloped root system supporting an extensive T. melanosporum mycelial network able to produce abundant black truffles in the future. Therefore, we examined the consequences of the weed control treatments on the expansion of T. melanosporum mycelium in soil 3 years after planting inoculated seedlings. No burns could be observed yet, but soils at 15 and $30 \mathrm{~cm}$ from the seedling stems were already colonized by the fungus in all treatments, indicating the appropriate proliferation of the fungus around the seedling's root system. Mycelial extension is needed for mycorrhizal formation (Kües and Martin 2011) and fungal fructification (Le Tacon et al. 2013), although no clear correlation of mycorrhizal percentages (Águeda et al. 2010), or mycelium quantity (Suz et al. 2008), with sporocarp production has been found. 
At $30 \mathrm{~cm}$ from the stem, median quantities of T. melanosporum mycelium were approximately a third of those at $15 \mathrm{~cm}$. T. melanosporum mycelium from plots treated with the double white mulch was significantly more abundant than in all other treatments indicating that a relevant reduction of herbaceous cover allows a better proliferation of the fungus.

Our estimates of absolute amount of mycelium are based on the assumption that our soil sample did not have any T. melanosporum spores. We believe this to be very likely since otherwise we would have detected truffle DNA 45 or $60 \mathrm{~cm}$ away from the stems as well, and this was not the case. Also, this experimental site had been cultivated for more than 10 years with fescue and barley, which are nonectomycorrhizal partners, before planting the inoculated seedlings. The range of our estimates, from 25 to $530 \mu \mathrm{g}$ of mycelium per gram of soil, obtained by means of conventional PCR followed by relative band intensity analysis is quite similar to that of 256 to $638 \mu \mathrm{g}$ per gram of soil observed by Parladé et al. (2013) in productive black truffle plantations using real-time PCR. Mycelial quantities are difficult to interpret with respect to ecological significance, but the differences among treatments that we have observed provide a baseline for further studies.

The technique used for quantification of T. melanosporum mycelium has been previously demonstrated to be efficient to test the T. melanosporum mycelium amount around $Q$. ilex trees (Suz et al. 2006, 2008) although quantitative aspects inferred from an intensity gradient of amplicons can be problematic when band intensities do not continue to increase after certain number of PCR cycles as previously signalled by Brüggemann et al. (2000). However, by analyzing the densities of the bands of the standard dilutions in each amplification, we know that the PCR reaction has not been saturated or limited.

The stone mulch and tillage plots were drier than the white double plots suggesting that soil temperature combined with a thick weed cover could promote greater soil water loss from the upper soil profile. This loss of soil water to the atmosphere may not be important for holm oaks, even in the driest periods. Black truffle mycorrhizae grow mainly in the top $30 \mathrm{~cm}$ of soil (Olivera et al. 2011) where aeration is important (Castrignanò et al. 2000). In the driest periods, when the upper soil layers could be more exposed to water limitation, the warmer soil temperature may be a limiting factor for the growth of the fungus. Although both $Q$. ilex and T. melanosporum have evolved in Mediterranean conditions, the high soil temperatures observed in this site for several of the treatments could be problematic for the proliferation of the fungal symbiont, and this could be critical in the future in the context of climate change (Büntgen et al. 2012). Optimum rhizosphere temperatures for T. melanosporum have been shown to be between 20 and $25{ }^{\circ} \mathrm{C}$ in controlled conditions (Bustan et al. 2006). Weed control to reduce water stress may not be sufficient to promote seedling growth if soil temperatures are too high.
In truffle orchards, we are interested not only in seedling growth and weed control but ultimately in the success of the T. melanosporum- $Q$. ilex symbiosis. We observe that T. melanosporum mycelium spreads radially beyond the mycorrhizosphere, and in this study, the greater expansion occurred in the plots with white double, where we also found greater seedling growth than in the untreated plots. Larger trees potentially have more available carbon to maintain larger quantities of ectomycorrhizae and mycelium biomass (Wallander 2006). These white double plots showed a moderate presence of weeds and lower number of dry and hot days. These combined characteristics were not observed in any of the other treatments applied and may have been the key to its success.

Seedling and fungal growth are not solely influenced by the reduction of weeds. The treatments applied here had effects beyond weed control that include modification of soil temperature, soil moisture content and reflected PPFD. When the ground is covered by reflective materials, the background reflected PPFD could contribute to increase the PPFD that the leaves can absorb (Pinty et al. 2011; Atkinson et al. 2006; Green et al. 1995). This effect may be relevant in Mediterranean climates where light in extended periods of spring and fall, and even winter, can be used for photosynthesis because temperatures are mild, and water is available, while in the summer, photosynthesis is often limited by lack of water (Peñuelas et al. 1998). In our study, the positive results on weed control, seedling growth and mycelium extension obtained by the white double mulch are in accordance with a higher percent of reflected PPFD, that was 5- to 8-fold higher in white single and white double than in the untreated plots and those with the black cover.

The woven polypropylene fabrics we used as mulch are porous enough to allow for rainfall infiltration as well as air circulation. This can explain why we did not find warmer temperatures under this black mulch compared with untreated plots. Studies using black plastic mulches with limited air circulation report increases of soil temperature (Díaz-Pérez and Dean Batal 2002; Ramakrishna et al. 2006).

The white polyethylene mulch, especially white double, reduced the number of days of high soil temperatures compared with the untreated plots. The number of days with mean soil temperatures higher than $28{ }^{\circ} \mathrm{C}$ was threefold greater in treatments with lower reflected PPFD - soil tilling, hand hoe, black single, black double and untreated plots - than in the most reflective white mulch plots. Higher root zone temperatures were observed with treatments where reflected PPFD were lower as has been observed by Díaz-Pérez and Dean Batal (2002) in a study with several coloured plastic film mulches. In what extension the expansion of T. melanosporum may be attributed to an increase of reflected PPFD is unclear since mulches modified other parameters than the reflected PPFD. However, we suggest that this 
parameter should be taken into account in further studies concerning T. melanosporum expansion. In conclusion, the use of both black single and black double mulches as well as white double seems to be more effective than the other treatments in weed control. In addition, the white double mulch treatment, with a higher solar energy reflected, maintained a lower soil temperature, allowing the maintenance of soil moisture, which, together with the control of the herbaceous cover, improves seedling growth and the spread of T. melanosporum mycelium in the environmental conditions of our study. Further research is needed to expand these results to other situations.

Acknowledgement We thank Lluís Bonet and Jordi Bonet for allowing us to use their truffle orchard to carry out this study and for their help in treatment application, C.R. Fischer for helpful suggestions and English support, and the reviewers and editors that helped improve the quality of this manuscript.

Funding This study was partially funded by the Subdirección General de Proyectos de Investigación, Ministerio de Ciencia e Innovación of Spain (research grant AGL2010-22354-C02-0) and by the Direcció General de Desenvolupament Rural, Departament d'Agricultura, Ramaderia, Pesca, Alimentació i Medi Natural, Generalitat de Catalunya.

\section{References}

Águeda B, Fernández-Toirán LM, de Miguel AM, Martínez Peña F (2010) Ectomycorrhizal status of a mature productive black truffle plantation. For Syst 19:89-97

Allen RG, Pereira LS, Raes D, Smith M (1998) Crop evapotranspiration. Guidelines for computing crop water requirements. FAO Irrigation and drainage paper 56, Rome

Atkinson CJ, Dodds PA, Ford YY, Le Miere J, Taylor JM, Blake PS, Paul N (2006) Effects of cultivar, fruit number and reflected photosynthetically active radiation on Fragaria $\mathrm{x}$ ananassa productivity and fruit ellagic acid and ascorbic acid concentrations. Ann Bot 97:429 441. doi:10.1093/aob/mcj04610.1093/aob/mcj046

Bonet JA, Fischer CR, Colinas C (2006) Cultivation of black truffle to promote reforestation and land-use stability. Agron Sustain Dev 26: 69-76. doi:10.1051/agro:2005059

Bourrieres D, Ricard JM (2008) Effects on soil management on the evolution of young plants mycorrhized with Tuber melanosporum. $3^{\circ}$ Congresso Internazionale Di Spoleto Sul Tartufo. Comunità Montana del monti Martani e del Serrano, Spoleto, p 102

Brüggemann J, Stephen JR, Chang YJ, Macnaughton SJ, Kowalchuk GA, Kline E, White DC (2000) Competitive PCR-DGGE analysis of bacterial mixtures: an internal standard and an appraisal of template enumeration accuracy. J Microbiol Meth 40:111-123

Büntgen U, Egli S, Camarero JJ, Fischer EM (2012) Droughtinduced decline in Mediterranean truffle harvest. Nat Clim Chang 2:827-829

Bustan A, Ventura Y, Kagan-Zur V, Roth-Bejerano N (2006) Optimized conditions for mycorrhiza formation between the pink rockrose (Cistus incanus) and the black Pèrigord truffle (Tuber melanosporum). Isr J Plant Sci 54:87-96

Castrignanò A, Goovaerts P, Lulli L, Bragato G (2000) A geostatistical approach to estimate probability of occurrence of Tuber melanosporum in relation to some soil properties. Geoderma 98: 95-113
Colinas C, Capdevila JM, Oliach D, Fischer CR, Bonet JA (2007) Mapa d'aptitud per al cultiu de la tòfona negra (Tuber melanosporum Vitt.) a Catalunya. CTFC, Solsona

Davis MA, Wrage KJ, Reich PB, Tjoelker MG, Schaeffer T, Muermann C (1999) Survival, growth, and photosynthesis of tree seedlings competing with herbaceous vegetation along a water-light-nitrogen gradient. Plant Ecol 145:341-350

Díaz-Pérez JC, Dean Batal K (2002) Colored plastic film mulches affect tomato growth and yield via changes in root-zone temperature. J Am Soc Hortic Sci 127:127-136

Domínguez Núñez JA, Serrano JS, Barreal JAR, González JAS (2006) The influence of mycorrhization with Tuber melanosporum in the afforestation of a Mediterranean site with Quercus ilex and Quercus faginea. For Ecol Manag 231:226-233. doi:10.1016/j.foreco.2006. 05.052

Green SR, McNaughton KG, Greer DH, McLeod DJ (1995) Measurement of the increased PAR and net all-wave radiation absorption by an apple tree caused by applying a reflective ground covering. Agr Forest Meteorol 76:163-183

Guidot A, Debaud JC, Marmeisse R (2002) Spatial distribution of the below-ground mycelia of an ectomycorrhizal fungus inferred from specific quantification of its DNA in soil samples. FEMS Microbiol Ecol 42:477-486

Heißner A, Schmidt S, von Elsner B (2005) Comparison of plastic films with different optical properties for soil covering in horticulture: test under simulated environmental conditions. J Sci Food Agric 85: 539-548. doi:10.1002/(ISSN)1097-0010

Hytonen J, Jylha P (2005) Effects of competing vegetation and postplanting weed control on the mortality, growth and vole damages to Betula pendula planted on former agricultural land. Silva Fenn 39:365

Kües U, Martin F (2011) On the road to understanding truffles in the underground. Fungal Genet Biol 48:555-560. doi:10.1016/j.fgb. 2011.02.002

Kummel M, Lostroh P (2011) Altering light availability to the plant host determined the identity of the dominant ectomycorrhizal fungal partners and mediated mycorrhizal effects on plant growth. Botany Bot 89:439-450

Le Tacon F, Zeller B, Plain C, Hossann C, Brechet C, Robin C (2013) Carbon transfer from the host to Tuber melanosporum mycorrhizas and ascocarps followed using a $13 \mathrm{C}$ pulse-labeling technique. PLoS One 8(5):e64626. doi:10.1371/journal.pone.0064626

Lefevre C, Hall I (2001) The status of truffle cultivation: a global perspective. V International Congress on Hazelnut, ISHS, Corvallis, pp 513-520

Lipecki J, Berbec S (1997) Soil management in perennial crops: orchards and hop gardens. Soil Tillage Res 43:169-184

Littell RC, Milliken GA, Stroup WW, Wolfinger RD, Schabengerger O (2006) Analysis of repeated measures data, in SAS for mixed models. 2nd. SAS Institute Inc. Carry, edn pp 159-202

Martínez de Aragón J, Fischer C, Bonet JA, Olivera A, Oliach D, Colinas C (2012) Economically profitable post fire restoration with black truffle (Tuber melanosporum) producing plantations. New For 43: 615-630. doi:10.1007/s11056-012-9316-x

Navarro Cerrillo RM, Fragueiro B, Ceaceros C, del Campo A, de Prado R (2005) Establishment of Quercus ilex L. subsp. ballota [Desf.] Samp. using different weed control strategies in southern Spain. Ecol Eng 25:332-342. doi:10.1016/j.ecoleng.2005.06.002

Olivera A, Fischer CR, Bonet JA, Martínez de Aragón J, Oliach D, Colinas C (2011) Weed management and irrigation are key treatments in emerging black truffle (Tuber melanosporum) cultivation. New For 42:227-239. doi:10.1007/s11056-011-9249-9

Paolocci F, Rubini A, Riccioni C, Granetti B, Arcioni S (2000) Cloning and characterization of two repeated sequences in the symbiotic fungus Tuber melanosporum Vitt. FEMS Microbiol Ecol 34:139-146

Parladé J, Hortal S, Pera J, Galipienso L (2007) Quantitative detection of Lactarius deliciosus extraradical soil mycelium by real-time PCR 
and its application in the study of fungal persistence and interspecific competition. J Biotechnol 128:14-23

Parladé J, de la Varga H, de Miguel AM, Sáez R, Pera J (2013) Quantification of extraradical mycelium of Tuber melanosporum in soils from truffle orchards in northern Spain. Mycorrhiza 23: 99-106

Peñuelas J, Filella I, Llusia J, Siscart D, Piñol J (1998) Comparative field study of spring and summer leaf gas exchange and photobiology of the Mediterranean trees Quercus ilex and Phillyrea latifolia. J Exp Bot 49:229-238

Pinty B, Widlowski J-L, Verstraete MM, Andredakis I, Arino O, Clerici M, Kaminski T, Taberner M (2011) Snowy backgrounds enhance the absorption of visible light in forest canopies. Geophys Res Lett 38:1-5. doi:10.1029/2010GL046417

Rajapakse NC, Shahak Y (2007) Light quality manipulation by horticulture industry. In: Whitelam GC, Halliday KJ (eds) Annual plant reviews. Light and plant development, vol 30. Blackwell, Oxford, pp 290-312

Ramakrishna A, Tam H, Wani S, Long T (2006) Effect of mulch on soil temperature, moisture, weed infestation and yield of groundnut in northern Vietnam. Field Crop Res 95:115-125. doi:10.1016/j.fcr. 2005.01.030

Ramsey F, Schafer D (2002) The statistical sleuth: a course in methods of data analysis, $2 \mathrm{n}$ edn. Duxbury, Pacific Grove

Reicosky DC, Allmaras RR, Shrestha A (2003) Advances in tillage research in North American cropping systems. In: Shrestha A (ed) Cropping systems: trends and advances Part I. Haworth, New York, pp 75-125

Rey Benayas JM, Navarro J, Espigares T, Nicolau JM, Zavala MA (2005) Effects of artificial shading and weed mowing in reforestation of Mediterranean abandoned cropland with contrasting Quercus species. For Ecol Manag 212:302-314. doi:10.1016/j.foreco. 2005.03.032

Rubini A, Paolocci F, Granetti B, Arcioni S (1998) Single step molecular characterization of morphologically similar black truffle species. FEMS Microbiol Lett 164:7-12

Samils N, Olivera A, Danell E, Alexander I, Fischer CR, Colinas C (2008) The socioeconomic impact of truffle cultivation in rural Spain. Econ Bot 62:331-340. doi:10.1007/s12231-008-9030-y

SAS Institute Inc. (1999) The MIXED procedure, in SAS/STAT V8 User's Guide) SAS Institute Inc., Cary, pp 5234-5426

Saxton KE, Rawls WJ (2006) Soil water characteristic estimates by texture and organic matter for hydrologic solutions. Soil Sci Soc Am J 70:1569. doi:10.2136/sssaj2005.0117

Suz LM, Martin MP, Colinas C (2006) Detection of Tuber melanosporum DNA in soil. FEMS Microbiol Lett 254:251-257. doi:10.1111/j. 1574-6968.2005.00029.x

Suz LM, Martín MP, Oliach D, Fischer CR, Colinas C (2008) Mycelial abundance and other factors related to truffle productivity in Tuber melanosporum-Quercus ilex orchards. FEMS Microbiol Lett 285: 72-78. doi:10.1111/j.1574-6968.2008.01213.x

Verdú A, Mas M (2007) Mulching as an alternative technique for weed management in mandarine orchard tree rows. Agron Sustain Dev 27:367-375. doi:10.1051/agro:2007028

Wallander H (2006) External mycorrhizal mycelia - the importance of quantification in natural ecosystems. New Phytol 171:240-242

Zambonelli A, Iotti M, Zinoni F, Dallavalle E, Hall IR (2005) Effect of mulching on Tuber uncinatum ectomycorrhizas in an experimental truffière. N Z J Crop Hortic Sci 33:65-73

Zampieri E, Rizzello R, Bonfante P, Mello A (2012) The detection of mating type genes of Tuber melanosporum in productive and non productive soils. Appl Soil Ecol 57:9-15 